Загородня О.Ф., к. ф. н. Національна академія статистики, обліку та аудиту, м. Київ, Україна

\title{
ВИЩА ОСВІТА В УКРАЇНІ: ПРОБЛЕМИ ТА ПРІОРИТЕТИ РО3ВИТКУ
}

Вища освіта в Україні на сьогодні переживає низку труднощів і трансформацій. Це зумовлено актуальними проблемами в сучасній українській вищий школі, зокрема розбіжністю між потребами економіки та структурами підготовки спеціалістів, перенасичення ринку праці фахівцями 3 вищою освітою і нестача робітничих спеціальностей, процеси глобалізації і відтік українських студентів за кордон тощо [1]. Сучасним проблемам вищої освіти в Україні присвячені праці І.М. Вальдшмідта, М.П. Денисенко, Т.Ф. Погорєлової, С.О. Тульчинської, В. Петруняка та ін. [2 - 4].

3 причин недостатнього фінансування 3ВО, масовості вищої освіти, що не відповідає ринкам праці, підвищення вимог до якості освітніх послуг та кваліфікаційних навичок викладача вищої школи в Україні інтенсифікується конкурентна боротьба між навчальними закладами, яка дотична до породження так званої «студентської кризи», коли обсяги наборів у певні ЗВО значно скорочуються. Це спонукає вищі навчальні заклади України шукати нових шляхів залучення студентів до навчання, покращувати освітянські послуги і пропонувати студентству нові можливості отримання і реалізації здобутих знань і навичок відповідно до світових процесів глобалізації та євроінтеграції України.

В умовах стратегічного партнерства України з СС у сфері освіти та науки Національна академія статистики, обліку та аудиту (м. Київ, Україна, далі - НАСОА) підтримує освітянські, наукові та культурні зв'язки 3 профільними (економічними) вищими навчальними закладами Свропи. Партнерами Академії стали такі заклади у Франції (Університет Пантеон-Сорбонна Париж (Universite de Paris), Група національних шкіл 3 економіки та статистики (GENES)) і Польщі (Жешувський університет (Uniwersytet Rzeszowski), Вища банківська школа в Познані (WSB), Університет інформатики в Лодзі (Wyższa Szkoła Informatyki w Łodzi), Вища школа бізнесу в Домброві Гурнічій (WSB) та ін.) [5]. 
Важливим аспектом цієї співпраці є запроваджена програма мобільності студентів «Подвійний диплом», яка передбачає навчання українських студентів НАСОА впродовж декількох семестрів у закордонному вищому навчальному закладі країни-партнера (зокрема, Польщі) і отримання подвійного диплома з обраної спеціальності. Крім того, студенти за цією програмою мають можливість продовжувати у Польщі навчання за магістерськими програмами, а також проходити за кордоном практику, безкоштовне стажування тощо, тобто набувати новітніх професійних навичок, релевантних на міжнародному ринку праці, а також отримувати необхідний міжнародний досвід для впровадження його на теренах вітчизняної економіки.

Система навчання «Подвійний диплом» ставить перед адміністрацією та викладачами НАСОА низку завдань, зокрема завдання подолання мовних бар'єрів студентів для вдалої адаптації до навчання у Польщі. 3 огляду на це, у закладі впроваджено безкоштовну підготовку з польської мови паралельно з інтенсифікацією навчання англійської мови.

Можливість бути одночасно студентами українського національного i закордонного закладів в межах одного терміну навчання є досить привабливою пропозицією для сучасної, мобільної, орієнтованої на ЄС молоді, і це, з одного боку, сприяє залученню додаткової аудиторії до лав НАСОА завдяки розширенню перспектив навчання, а з іншого боку - допомагає подолати проблему дефіциту студентства в умовах теперішньої соціально-економічної і політичної ситуації в Україні, яка, на жаль, посилює орієнтацію молоді на виїзд з країни у майбутньому.

Ще одним кроком НАСОА для подолання студентської кризи $€$ інтенсивний розвиток підготовчого відділення із залученням на навчання студентів з Азербайджану, Туркменістану, Туреччини, Марокко. Впродовж терміну навчання на підготовчому відділенні іноземним студентам забезпечують базову підготовку з природничих, математичних і лінгвістичних дисциплін. Мовна підготовка передбачає викладання основ російської та англійської мов, на основі якої надалі викладають природничі та математичні дисципліни 3 урахуванням необхідної термінології для подальшого навчання закордонних студентів в українських 3ВО. Окремі групи іноземних студентів після проходження підготовчої програми стають студентами НАСОА, що значно збільшує можливості академічного розвитку закладу.

Реалізація програми мобільності студентів на основі системи навчання за подвійним дипломом, надання нових можливостей 
якісного навчання в Україні студентам 3 країн Близького Сходу сприяють посиленню соціально-культурних і освітянських зв'язків, інтенсифікують обмін професійним досвідом у сферах економіки, тимчасово вирішують проблему дефіциту студентів в українських ЗВО, спонукають до покращення якості освіти та розширення освітніх програм з урахуванням мультикультурності студентської аудиторії ЗВО, а це, в свою чергу, сприяє загальній модернізації вищої освіти в сучасній Україні.

\section{Список бібліографічних посилань}

1. Глобальні тенденції і проблеми розвитку освіти: наслідки для України. Національний інститут стратегічних досліджень. URL : http://www.niss.gov.ua/articles/1537/

2. Вальдшмідт І.М. Основні проблеми системи вищої освіти в Україні та шляхи іiї модернізації. Економіка та держава. 2014. №6. C. $152-155$.

3. Денисенко М.П. Вища освіта в Україні: проблеми та перспективи. Вчені записки університету «КРОК». 2013. Вип. 33. С. 17 - 24.

4. Погорєлова Т.Ф. Місія університетської освіти в умовах глобалізації світової економіки. Стратегія розвитку України: економічний та гуманітарний виміри: матеріали III-ї Міжнар. наук.практ. конф. (Київ, 17 жовтня 2016 р.). Київ: НАСОА, 2016. C. $399-401$.

5. Основні університети-партнери за кордоном. Національна академія статистики, обліку та аудиту. Офіційний сайт. URL : http:// nasoa.edu.ua/mizhnarodna-diyalnist/navchannya-kordonom/ 